\title{
Risk Considerations in Legalized Dispute Settlement (DS) Mechanisms: \\ Risk Reduction, Risk Creation, and the WTO DS System
}

\author{
Don Moon \\ (KyungHee University)
}

\section{$\langle$ Content $\rangle$}

I. Introduction

II. Literature Review

III. Risk Reduction, Utility Enhancement, and the Legalized DS System
IV. Risk Reduction under the WTO DS System
V. Risk Creation by the Legalized DS Mechanism
VI. Conclusion

- Key Words: WTO, Dispute Settlement System, Risk/Uncertainty, Utility Enhancement, International Legalization

\section{【ABSTRACT 】}

Focusing on the World Trade Organization (WTO), this paper explores two contrasting risk/uncertainty considerations over a legalized dispute settlement (DS) mechanism: risk reduction and risk creation. One of the incentives for states to establish a legalized DS mechanism is to reduce the risk/uncertainty involved in dispute resolution and to increase the utility of dispute outcomes. Due to the four features of the legalized DS system clear substantive rules, well-established procedural rules, independent legal bodies, and legal precedents the legalized DS system tends to produce dispute outcomes with narrower variations and smaller fluctuations, as compared with the non-legal bargaining DS system. On the other hand, the legalized DS system also creates risk resulting from the independence of the legal institutions. Because states are concerned that the actual dispute outcomes made by the independent legal bodies may deviate from their expectations at the time of the original legalization agreement, they try to limit the authority of the legal bodies by using various measures. 


\section{Introduction}

In recent years, international law and international legal bodies have played increasingly significant roles in resolving disputes and conflicts. States are willing to reach legal agreements that impose considerable constraints on their behaviors and to delegate part of their authority to independent legal institutions. Why do states enter into legally binding dispute resolution mechanisms? What kinds of incentives make states reach an agreement to establish independent legal bodies and to obey their decisions? One of the incentives for states to establish a legalized DS mechanism is to reduce the risk/uncertainty involved in dispute resolution and to increase the utility of dispute outcomes. ${ }^{1)}$

Although many studies have addressed risk/uncertainty problems in the context of international institutions, there has been no serious examination concerning the different aspects of risk/uncertainty problems. The concept of risk, as well as the relationships between institutional arrangements and risk considerations, has been discussed in a very partial and unsystematic way. With relation to international legalization, I will discuss the following two contrasting types of risk/uncertainty problems: risk reduction and risk creation.

First, legalization reduces the risk/uncertainty involved in dispute resolution and increases the utility for the disputing states (risk reduction as a result of legalization). The legalized DS system is organized on the basis of clear substantive and procedural rules. Binding decisions are made by the independent legal bodies with delegated authority from the member states. Thus, the legalized DS system can decrease the fluctuation of and increases the predictability of dispute outcomes, as compared with the non-legal bargaining DS system. Assuming that disputing states have risk-averse utility functions, legalization improves utility by reducing the variations of dispute outcomes.

Second, although legalization reduces one type of risk/uncertainty, it also creates another type of risk resulting from the independent legal bodies and legal precedents (risk creation by legalization). Because the binding decisions made by the legal bodies have significant and accumulative distributive impacts on states, states have serious concerns that the actual dispute outcomes produced by the legal bodies may deviate from the original expectations at the time of the legalization agreement. Thus, states need to introduce various adjustment and control mechanisms when they agree to establish a

1) There are several other incentives for constructing the legalized DS system. Reducing the direct costs for dispute resolution is one of the incentives. The expectation of favorable distributive outcomes through the legalized system can be another incentive. About these incentives, see Abbott and Snidal (2000), Moon (2002). 
legalized DS system.

The remainder of this article consists of five sections. In the next section, I will review the general arguments about risks and uncertainties from the transaction cost perspective. The third section presents several models of risk reduction through legalization. Using an analogy with insurance, these models will demonstrate how legalization reduces risks and, as a result, increases the utilities of the disputing states. In the fourth section, I will apply a theoretical argument of risk reduction to the studies of the GATT/ WTO. By examining the legal provisions and the operation of legal bodies of the GATT/ WTO, I will demonstrate how the legalized system of the WTO reduces the variation of dispute outcomes as compared with the GATT period. The fifth section deals with the risk-creation effect of legalization, which results from the independence and delegated authority of the legal bodies. The final section concludes this study.

\section{Literature Review}

Let us begin with some conceptual clarifications. In his pioneering work Risk, Uncertainty, and Profit (1971/1921), Knight differentiates risk and uncertainty on the basis of whether the probability distribution over outcomes is known (risk) or not (uncertainty). Thus, risk is the measurable uncertainty through calculation a priori or from statistics of past experience (p. 233). As for a method for meeting risks and uncertainties, he suggests consolidation (grouping: offsetting the losses from some bad decisions by the gains from other good decisions in the groups of cases) and specialization (shifting the risk to the professional speculator who can use hedging contracts for diffusing risks) (pp. 233-263).

The recent trend in economics has been away from differentiating risk and uncertainty, simply (and reasonably) assuming that the probability function of uncertainty is evenly distributed. Alternatively, transaction costs economics (TCE) has developed the classification of three different types of uncertainty rising from various information problems. The first type of uncertainty, called primary uncertainty, is uncertainty to the state coming from unknown future contingencies and changes. The second type of uncertainty is uncertainty that results from lack or insufficiency of communication (Koopmans 1957). The third type of uncertainty, which has been the main focus of economic research, is behavioral uncertainty that comes from economic actors' strategic behavior of hiding or distorting information for their own interest (Williamson 1979, 1989). Adverse selection problem and moral hazard problem are two examples that result from behavioral uncertainty. 
How, then, does TCE suggest solutions for reducing risks? Centralized and delegated institutional arrangements, such as firm-merging, can be a solution. Among various empirical studies, Helfat and Teece (1987) compellingly demonstrate how vertical integration, executed by merger, can reduce a firm's systematic or undiversifiable risks (p. 47). Helfat and Teece claim that internal organization facilitates information flows through communication codes and attenuates the incentives for strategic distortion and nondisclosure of necessary information.

In the international relations (IR) field, recent studies of rational institutional design (International Organization, Special Issue, 2002 Summer) explore how institutions handle uncertainty problems through centralization. In the analysis of international commercial arbitration, Mattli (2002) argues that the extent of centralization increases with the uncertainty about the parties' preferences/behaviors and about the state of the world. He correctly indicates that institutional arrangements with centralized functions can reduce transaction costs involved in monitoring, adjudication, and enforcement. However, his argument, like most of the other institutionalist arguments, does not consider the utility improvement effect of institutions as a result of reducing risks. ${ }^{2}$ )

In spite of recent interest in international legalization, there has been no systemic analysis regarding the relationships between the legalization and risk/utility consequences. The main focus of this article is to comprehensively explore various aspects of risk/uncertainty problems in the context of international legalization and legalized dispute resolution mechanisms.

\section{Risk Reduction, Utility Enhancement, and the Legalized Dispute Settlement System}

\section{How International Legalization Can Reduce Risks and Uncertainties}

Risk aversion means that rational actors, in general, prefer sure outcomes to outcomes with variances, or they prefer outcomes with smaller variances to outcomes with bigger

2) In a broader sense, the risk problem is one kind of transaction cost problem that encompasses rule-making, monitoring, adjudication, and enforcement. The key aspect of the risk problem is the uncertainty involved in other actors' preferences/behaviors or in the state of the world. That is, the risk problem refers to sub-optimality caused by the variation and unpredictability of outcomes. When we discuss risk reduction and utility improvement achieved by certain institutional arrangements (here, a legalized DS system), the concept of risk needs to be used in a strict way that captures how those institutional arrangements reduce the variation of outcomes and improve the utility of the participants. 
variances, even if both outcomes have the same expected values. Risk aversion is based on the notion that the marginal utility of payoffs decreases with an increase of payoffs, which has generally been accepted in economics.3) Basic microeconomics theory describes the relationships between the risk-averse utility functions and the incentives of insurance purchase. Rational actors are willing to pay a certain amount of money in order to reduce or eliminate risks. Buying insurances is the most common example in real life. Because the premium of insurance includes certain amount of maintenance costs in addition to costs for fair compensation, buying insurance implies a loss of payoffs (incomes). However, the loss in actual payoffs can be outweighed by the increased utility of the sure payoffs that are covered by the insurance.

As rational individuals are willing to pay premiums for reducing risks, rational states are also willing to incur certain costs for reducing risks involved in their transactions. If we use the analogy of insurance, the cost for constructing institutions and for arranging states' relations in the institutional framework is similar to insurance premiums. Reducing risks and uncertainties, along with other transaction costs considerations, is one of the incentives for states to establish various institutions. As one type of institutionalization, international legalization also can be explained on the basis of risk-reduction considerations. States agree to legalize dispute settlement mechanisms because legalization decreases the degrees of the fluctuation of expected outcomes, as compared with the non-legal bargaining mechanism of dispute settlement. Thus, it can increase the utilities of legally binding actors who are risk-averse.

Then, how can legalization reduce risks/uncertainties of resolving disputes? It is because the legalized system more or less fixes the payoffs (or reduces the variances of dispute outcomes) ex ante, as compared with an open-ended bargaining for resolving disputes. First, a legal mechanism is based on substantive rules that clarify the content of agreements, the rights and obligations of participants, and the kinds of behaviors allowed or not in the light of law. The substances provided by legal arrangements have advantages in transmitting clear meanings of the agreements, because legal text and languages are, in general, more likely to be well-defined, systematically organized, and logically consistent. Due to the precise and highly obligated substances, a legalized DS mechanism leaves relatively little room for arbitrary interpretation and application of the provisions in one's favor.

Second, the legalized system also contains well-established procedural rules that provide guideline on how actors should behave in order to handle unforeseen

3) One of the subfield in economics, which is called Behavioral economics (BE), challenges to the assumption of marginally diminishing utility functions, more fundamentally, to the conventionally accepted rationalist assumptions. For an interesting introduction for BE, see Mullainathan and Thaler (2000). 
contingencies, resolve disputes, and implement legal decisions. As the later GATT period revealed, obscurely defined procedures themselves were a source of disputes among states. A legalized mechanism enables states to follow pre-agreed upon processes in negotiating mutually agreeable solutions, filing or defending cases against each other, and requesting or offering appropriate amount of remedies for violations. The procedural rules impose certain restrictions on the behavior of the participants, and, thus, they reduce the possibility that each state will use its power arbitrarily and discriminatorily in dispute resolution and enforcement.

Third, the establishment of the independent legal body is critical in reducing the risks/uncertainties involved in dispute resolution. The dispute settlement body is empowered with delegated authority from the member states in interpreting the general legal provisions and applying them to the specific cases at hand. The judges and arbitrators of the legal body are selected among well-qualified candidates with legal expertise and distinguished experience. The secured position of the judges for a certain period of time enables them to examine the case and draw legal decisions relatively free from the interference of the disputing countries. As compared with the power-based dispute resolution mechanism, the judicial or quasi-judicial system increases the quality of legal decisions and enhances the predictability of a dispute outcome.

Finally, as disputes are filed and accumulated under the legalized system, the previous legal decisions function as legal precedents, which help states to anticipate future outcomes through the litigation process more accurately. The WTO agreements, more broadly international law in general, do not adopt stare decisis principle, which means that the former decisions do not have binding powers as legal precedents, at least in a formal way. However, it is without doubt that former decisions have significant impacts on the future behavior of disputing states as well as the judges. Under the direct/indirect shadow of law, states may correct their problematic practices even before legal actions are pursued, or they may reach mutually satisfactory solutions more easily and expeditiously. Likewise, the judges facing new cases and legal issues consult former decisions for the purpose of maintaining legal consistence and coherence.

Because of the four factors mentioned above substantive rules, procedural rules, independent legal bodies with delegated authority, and legal precedents the dispute outcomes produced by the legalized DS system have considerably lower degrees of variations and higher degrees of predictability than dispute outcomes produced by the non-legal bargaining DS system. Disputes reflect the conflicts of interests among states, and they also accompany various uncertainties as to what will be the final consequences. The outcome with lower variance and higher predictability is, in general, much preferred to the outcome with higher variance and lower predictability, since the utility of the former outcome is higher than that of the latter.

\section{Models of Risk Reduction Through Use of the Legalized DS Mechanism}

This section applies the analogy of insurance to the legalized DS system. If states 
resolve disputes through the legalized system, the dispute outcomes tend to show lower variances and narrower fluctuations than the outcomes through non-legal bargaining mechanisms. Figure 1 presents a one-actor model that illustrates how low-variance dispute outcomes improve utility of the states who are risk-averse. The horizontal axis measures the payoff (outcome) and the vertical axis measures the utility.

[Figure 1] Expected Utility under the Non-legal DS System and the Legal DS System

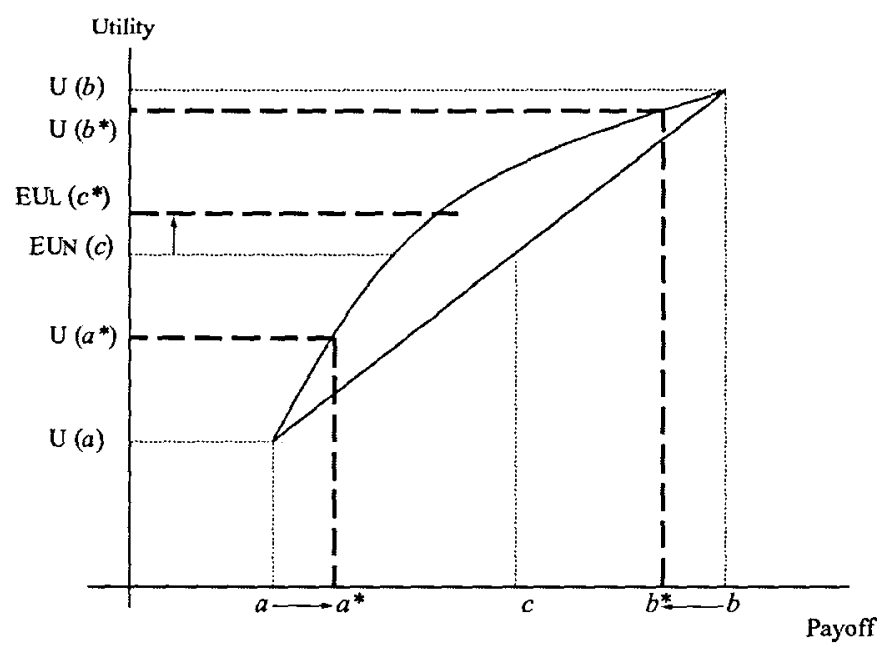

Let us assume that a state uses a non-legal bargaining mechanism for dispute resolution. The dispute outcomes have variances from $a$ with probability $p$ (payoff of losing the case) to $b$ with probability $1-p$ (payoff of winning the case). The expected payoff under the non-legal system will be $c \mathrm{~N}=\mathrm{a} \times p+\mathrm{b} \times(1-p)$. The expected utility of the state under the non-legal system is the weighted average of $U(a)$ and $U(b)$. That is, $\operatorname{EUN}(c)=\mathrm{U}(a) \times p+\mathrm{U}(b) \times(1-p)$.

Let us consider the situation in which the state uses a legal mechanism for dispute resolution. Because the legalized mechanism reduces the variation of dispute outcomes, the boundary of the outcomes narrows from $a$ to $a^{*}$ and from $b$ to $b^{*}$. Thus, under the legalized DS system, the expected payoff is $c^{*} \mathrm{~L}=a^{*} \mathrm{x} p+b^{*} \mathrm{x}(1-p)$, which is exactly the same value as that produced by the non-legal DS system $\left(c^{*} \mathrm{~L}=c \mathrm{~N}\right)$. However, the utility from the payoff is different under the two systems. Under the legalized DS system, the expected utility for the state is EUL $\left(c^{*}\right)=U\left(a^{*}\right) \times p+U$ $\left(b^{*}\right) \times(1-p)$. As Figure 1 shows, because of the concave utility function of the state (risk aversion), EUL $\left(c^{*}\right)>\operatorname{EUN}(c)$. That is, the legalized DS system increases the utility of the actor by reducing the variation of the dispute outcome.

Now let us discuss a two-actor dispute resolution model. Figure 2 shows why actors 
prefer a legalized mechanism to a non-legal mechanism even when the payoffs produced by the two mechanisms are exactly same. For simplicity reasons, I assume that legalized DS system produces fixed outcomes (instead of low-variance outcomes) with no variation s.4)

In figure 2, Line $a$ and $b$, respectively, represent state A's and B's payoffs, which are measured on the horizontal axis. Curve $a$ and $b$, respectively, represent state A's and B's utilities, which are measured on the vertical axis. Given that both states have risk-averse (concave) utility functions, both state $\mathrm{A}$ and $\mathrm{B}$ receive higher utility under the legalized DS system than they do under the non-legal DS system. That is, because the legalized DS system reduces the variation of dispute outcomes, it improves utilities for disputing actors as compared with the non-legal DS mechanism.

\section{[ Figure 2 ] Utility Enhancement and Facilitation of Dispute Resolution through the Legalized DS Mechanism}

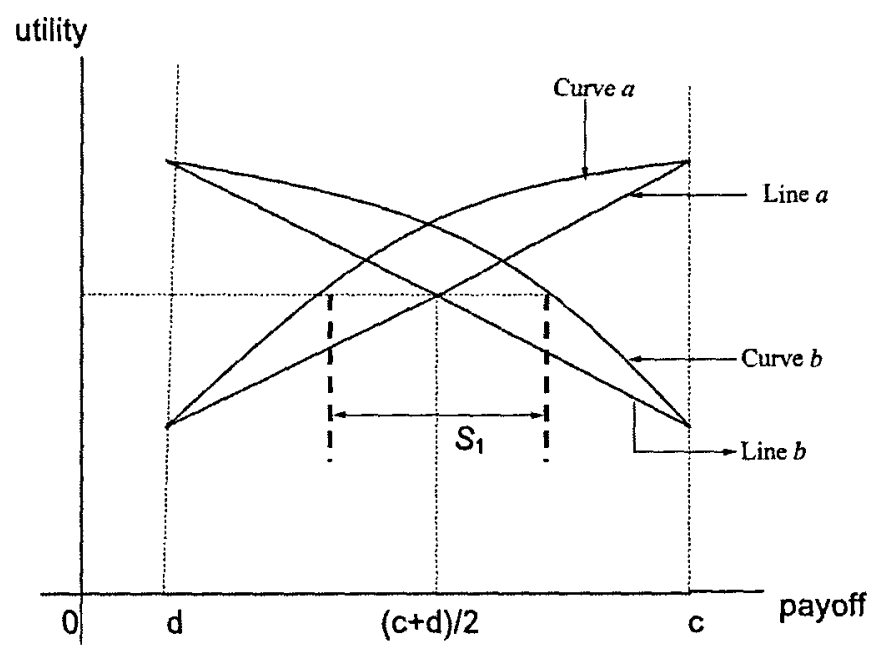

Figure 2 reveals that legalization facilitates resolving disputes, since it widens the bargaining space for reaching mutually acceptable solutions. That is, if states resolve disputes through the legalized DS mechanism, they are more likely to reach dispute

4) This model assumes perfectly operating ideal type of the legal system, which eliminates the variations of dispute outcomes and provides perfect predictability. Of course, in reality, no dispute resolution system can eliminate the uncertainties and variances of dispute outcomes completely. A legalized DS system only can reduce the degrees of variations. However, this modeling is designed to demonstrate the utility enhancement effect of legalization in a simple way. Even if we loosen the assumption of perfectly operating system, the central finding of this model -utility improvement by producing less fluctuating outcomes -does not change at all. 
settlement than if they resolve disputes through the non-legal mechanism. Let us assume that state $\mathrm{A}$ and $\mathrm{B}$ have exactly the same bargaining power (i.e., $p=0.5$ ) and the same expected payoffs (i.e., $(c+d) / 2$ ). By transforming the DS system from a non-legal to a legalized one, both states increase their utilities. In the above figure $2, S_{1}$ represents extended bargaining space, which comes from reducing risks and increasing utilities as a result of the legalized DS system. The logic is similar to insurance purchase: because a sure outcome produced by legalization gives high utilities even after subtracting a certain amount of payoffs (here, within the boundary of $S_{1}$ ), each state is willing to give concessions to its partner and to conclude disputes.

We can derive the following proposition about the relationships between risk-averse states and legalization: as compared with the non-legal bargaining DS mechanism, the legalized DS mechanism reduces risks (uncertainties) of dispute outcome and, thus, increases the utilities of legally bound actors who are risk-averse. This explains one of the incentives for legalization agreements.

\section{Different Degrees of Risk Aversion and the Legalized DS Mechanism}

This section takes into account different degrees of risk aversion between two actors and explores how the differences have effect on bargaining over the legalization agreement. States may have different degrees of risk-aversion for various reasons. The economic or political regime type of each state, leaders' individual personalities, or even different national characteristics may contribute to the diversities. However, this section considers a more plausible and significant factor in the real international economic relations: asymmetric trade dependence and vulnerability caused by it (Hirschman 1980 (1945), Keohane and Nye 1989). The higher is one country's portion of trade in the country's total economy (which is represented by the trade / GDP ratio) or the higher is one country's portion of export to its trade partner in one country's total export, we can assume that one country is more dependent and vulnerable to its partner in trade relationships.

Trade disputes tend to be more serious for the country with a higher degree of dependence and vulnerability. If this country loses the case in a dispute, the damage caused by the loss more deeply affects the whole economy. That is, the utility function of the country is more concave than that of its partner. Similarly, if stalemated disputes inflict negative effects on the whole trade relationships, the negativity is a more serious concern to the highly dependent country. If disputes are resolved purely on the basis of power instead of pre-agreed upon rules and procedures, highly dependent and vulnerable state has to face a continuous threat of power play and to accept unfavorable dispute outcomes. 
If one country is more dependent on and vulnerable to its trade partner, the country has a highly risk-averse utility function and a higher incentive to introduce the legalized DS system than its partner. Let us consider state $\mathbf{H}$ (a highly risk-averse state) and state $\mathbf{L}$ (a low risk-averse state) in figure 3. State $\mathbf{H}$ is more risk-averse than state $\mathbf{L}$, which implies that $\mathbf{H}$ is more willing to avoid outcomes with variances produced by the non-legal bargaining mechanism than state $\mathrm{L}$, even when both state $\mathrm{H}$ and state $\mathrm{L}$ have the same expected payoffs for dispute outcomes. Because the sure outcome through the legalized DS mechanism gives higher utilities to state $\mathbf{H}$, state $\mathbf{H}$ prefers a legalized DSM to a non-legal DSM than state $\mathbf{L}$ does.

By extending our logic, we can extract interesting implications as to how the different degrees of risk aversion have effects on the bargaining when states initially reach an agreement to establish the legalized DS system. Existing bargaining theory teaches us that a more patient actor enjoys an advantageous bargaining position and, as a result, acquires more favorable outcomes in negotiation. Likewise, the lower risk-averse actor can acquire more favorable outcomes than the higher risk-averse actor in the bargaining over the legalization agreement. The advantageous bargaining position comes from the different degrees of risk aversion. Because the higher risk-averse state $(\mathbf{H})$ has a stronger incentive for legalization than does the state with lower risk-aversion $(\mathbf{L})$, state $\mathbf{H}$ is willing to give certain concessions to state $\mathrm{L}$ in order to reach the legalization agreement. In the following figure 3 , let us assume that two states have the same bargaining power except for the differences in the degrees of risk-aversion.

Because the two states have the same probability of winning (0.5) and the same expected payoffs $((c+d) / 2)$ under the non-legal DS system, we can anticipate that the legalized DS system produces exactly the same dispute outcomes between the two actors. However, due to the different degrees of risk aversion, the point of intersection between the two utility curves $\left(E^{*}\right)$ lies on the right side of the even point (i.e., $(c+d) / 2$ ), which implies that the agreement of the legalized DS system requires certain concession for the high risk-averse state to the low risk-averse state.

From figure 3, we can induce another proposition concerning the different degrees of risk aversion and the legalization agreement: When the degrees of risk aversion are different among actors, a highly risk-averse state has stronger incentives for legalization than a less risk-averse state, and is willing to give concessions to the low risk-averse state in order to reach the legalization agreement. 
[Figure 3] The Different Degrees of Risk Aversion and the Legalization Agreements

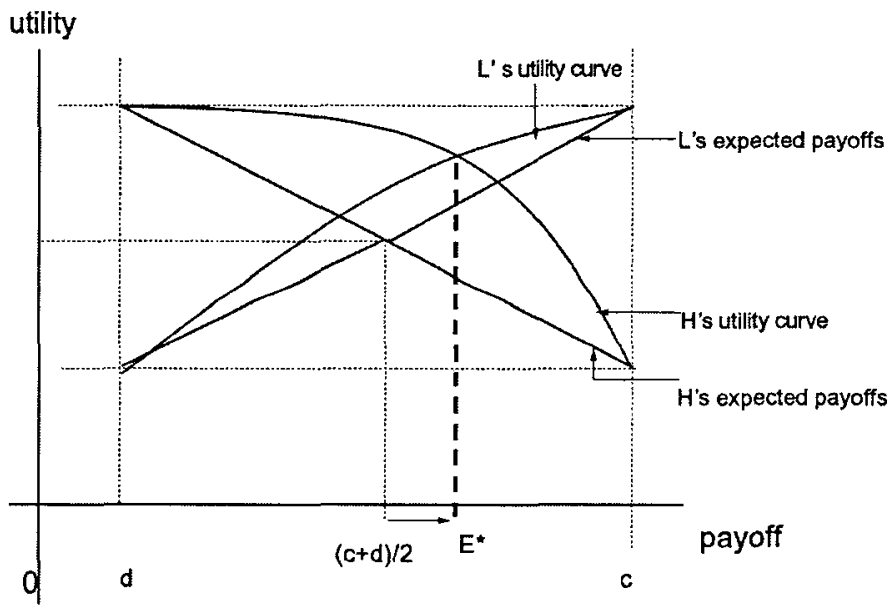

\section{Risk Reduction Under the WTO DS System}

In the previous section, I argued that legalization reduces risks/uncertainties involved in dispute resolution by providing (1) clear substantive rules, (2) well-established procedural rules, (3) independent legal bodies with delegated authority, and (4) legal precedents. I also contended that reducing risks and thereby increasing utilities is one of the incentives for states to establish a legalized DS mechanism. In this section, I will examine the concrete WTO agreement that contains various substantive and procedural rules, and I will analyze how the new WTO system reduces risks and improves predictability as compared with the old GATT system.

\section{Risk Reduction as a Result of the Substantive of the WTO Agreement}

The total of 26,000 pages of text exemplifies how wide and complicated are the issues dealt with in the WTO Agreement. The WTO Agreement incorporated various new issues in the multilateral trade agreement for the first time, and it clarified the obscure provisions of the old GATT Agreement. Because the WTO Agreement has quite a complicated organization and interconnection among its parts, it is useful to briefly describe the overall structure of the WTO Agreement. The text of the WTO Agreement itself is relatively simple; it relates to the establishment of the multilateral trade organization. All major substances of the Agreement are covered under the four Annexes, and each of the Annexes includes a great number of separate Agreements and/or Understandings. 
As table 1 shows, Annex 1A makes up the most important and largest portion of the WTO Agreement, and it provides the comprehensive substance of the multilateral trade agreement. Annex 1A General Agreements on Tariffs and Trade 1994 is commonly known as GATT 94. It modifies GATT 47 texts and consists of thirty-eight articles, each of which manifests the key principles and rules of trade agreements. GATT 94 also includes 12 separate Agreements and six Understandings relating to specific GATT articles and the Marrakesh Protocol. Due to the detailed text of each Agreement and Understanding, GATT 94 significantly clarified the rules and procedures, as compared with GATT 47 or Tokyo Round Agreements.

[ Table 1] The Content of the WTO Agreement

\begin{tabular}{l}
\hline Agreement Establishing the World Trade Organization (WTO Agreement) \\
\hline Annex 1 \\
\hline Annex 1A Multilateral Agreements on Trade in Goods (GATT 94) \\
\hline Agreement on Agriculture (AA) \\
\hline Agreement on the Application of Sanitary and Phytosanitary Measures (SPS) \\
\hline Agreement on Textile and Clothing (ATC) \\
\hline Agreement on Technical Barriers to Trade (TBT) \\
\hline Agreement on Trade-Related Investment Measures (TRIMs) \\
\hline Agreement on Implementation of Article VI (Anti-Dumping) \\
\hline Agreement on Implementation of Article VII (Customs Valuation) \\
\hline Agreement on Preshipment Inspection \\
\hline Agreement on Rules of Origin \\
\hline Agreement on Import Licensing Procedures \\
\hline Agreement on Subsides and Countervailing Measures (SCM) \\
\hline Agreement on Safeguards \\
\hline Annex 1B General Agreement on Trade in Services and Annexes (GATS) \\
\hline Annex 1C Agreement on Trade-Related Aspects of Intellectual Property Rights (TRIPs) \\
\hline Annex 2 Understanding on Rules and Procedures Governing the Settlement of Disputes (DSU) \\
\hline Annex 3 Trade Policy Review Mechanism (TPRM) \\
\hline Annex 4 Plurilateral Trade Agreement \\
\hline Agreement on Trade in Civil Aircraft \\
\hline Agreement on Governmental Procurement \\
\hline International Dairy Agreement \\
\hline International Bovine Meet Agreement \\
\hline International Economic Relations. p. 1. \\
\hline Source: Jackson, Davey, and Sykes (1995) Documents Supplement to Legal Problems of \\
\hline
\end{tabular}


Under the GATT system, lack of legal texts and obscurely defined provisions allowed the states for opportunistically pursuing protective and, in return, excessively retaliatory behaviors, and that was the source of continuous trade conflicts. Or even when states had no intention of flagrant cheating, many of the disputes involved good faith clashes over ambiguous terms of the bargain (Schwartz and Sykes 2001). Without clear substance of law, it is extremely difficult to constitute legal obligations and violations as well as to claim remedies on the breaches of the obligations.

During the Uruguay Round negotiations, which continued for more than eight years, states negotiated intensively to correct the fundamental flaws caused by the insufficient substantive and procedural rules of the GATT. The results of the comprehensive negotiation were organized systematically into various agreements. New trade issues that had become increasingly important in the global economy, such as intellectual property rights, services, and trade-related investments, were included in the WTO Agreement. Loosely defined rules in agriculture, anti-dumping, subsidies, technical barriers, and safeguard measures all of which had been the major sources of disputes were amended and clarified significantly. Now states could resolve disputes using the unambiguous provisions of the WTO Agreement and thus they could reduce conflict and confusion resulting from arbitrary interpretation and application of obscure provisions.

Let us take an example of agricultural disputes that highlight how changes of the substantive provisions under the WTO could reduce the uncertainties in dispute resolution as compared with the GATT system. Agricultural disputes had been one of the hottest controversies among states during the GATT period. The general principles of Most-Favored-Nation (MFN) Treatment and National Treatment, which were manifested in GATT Articles I and III, respectively, were too abstract to resolve disputes, and there was no separate agreement for exclusively dealing with agricultural products. What made these disputes more complicated was that most agricultural products were heavily supported by export subsides and/or protected by domestic subsides. In addition, complex protective measures were used by most countries, such as technical barriers, exceptional clauses, and domestic regulations for various reasons. The code system introduced in the Tokyo Rounds could not solve problems due to its obscure and insufficient texts.

When agricultural disputes were filed under the GATT system, the variations of the dispute outcomes were usually very wide depending on conditions related to the specific case. Defendant states frequently delayed the litigation process or blocked the adoption of panel decisions. Their behaviors could be justified because agricultural issues were not properly covered by the GATT Agreements and the DS procedures allowed the right of blockage. However, a dilatory or blockage strategy was not always successful especially 
when powerful complainants resorted to unilateral measures. For example, the US frequently used the Section 301 provisions in agricultural disputes and threatened to retaliate unilaterally regardless of the GATT DS process.

It should be noted that the US also could not always extract satisfactory concessions even by threatening unilateral retaliation. In the face of strong resistance by the target countries such as a threat of counter-retaliation or of mobilizing domestic and international public opinions the US as often as not had to back down or significantly mollify retaliatory threats. The outcome of agricultural disputes was usually determined by the complex political compromise linking several dispute cases as a package deal.

The paralysis of the GATT DS mechanism, exchanges of threatening unilateral retaliations and counterretaliations, and complicated political bargaining for concluding disputes --these were frequently witnessed in agricultural disputes during the later GATT period. Thus, both the complaining states and the defending states had difficulties in anticipating the result of disputes and faced high uncertainties regarding dispute resolution because of the wide variations of the outcomes. In the disputes, these uncertainties entailed considerable costs for the exporters and importers of those agricultural products. Unstable environments for businesses unpredictability as to whether retaliatory tariffs would be imposed or how high the tariff rates would be not only increased the direct costs of transactions but also diminished the overall incentive of trading those products.

Because agricultural disputes had involved various complicated issues that had many loopholes, the states needed to reach an agreement on all related provisions simultaneously. Without this comprehensive approach, clarifications on certain legal texts would be easily nullified by other obscure provisions. Thus, the Uruguay Round negotiations resulted in the Agreement on Agriculture, the Agreement on Subsidies, the Agreement on Sanitary and Phytosanitary Measures (SPS), and the Agreement on Technical Barriers to Trade (TBT), and so on. The Agricultural Agreement manifests that general principles of the MFN and National Treatment should be applied to agricultural products without exceptions. The Agreement on Subsidies prohibits export subsidies and freezes the amount of domestic subsidies. All subsidies are supposed to be reduced incrementally following the agreed upon time schedules and to be eliminated ultimately after the transition periods. The SPS and TBT require that states should prove legitimate and appropriate reasons (e.g. public health) in order to implement various regulations and standards. The purpose of these strict obligations is to prohibit state from using domestic regulations as protective measures.

In sum, the newly introduced agreements, as well as amended provisions, could clarify the terms of agreements, convey precise meanings of legal text, and differentiate legally 
allowable behaviors from unacceptable violations. Thus, now states could resolve agricultural disputes using the legal provisions of the WTO Agreement, and could predict the dispute outcomes much better than they had done under the GATT system.

\section{Risk Reduction as a Result of the Procedural Rules of the WTO Agreement}

In addition to substantive ambiguities, vaguely defined procedural rules of the GATT aggravated the problem of uncertainty. General dispute settlement procedures under the old GATT were expressed in the Article XXII (Consultation) and XXIII (Nullification or Impairment), which were not clear enough to set uncontroversial guidelines and time limits. Moreover, the GATT procedures frequently conflicted with various code procedures that had been employed since the Tokyo Rounds. Many disputes, especially domestically sensitive issues such as agricultural products, consumed considerable time with deciding which procedure should be adopted and where the dispute should be handled, this even before the formal litigation process began. The weak bindingness and ambiguity of the dispute settlement rules in the old GATT system produced highly uncertain and unpredictable dispute outcomes.

Because disputes were mainly determined on the basis of bargaining power rather than preagreed-upon rules and procedures, the outcomes tended to show wide variations. Using the loopholes of unclear procedural rules blocking the adoption of panel decisions was an example disputing states were able to maneuver various negotiation strategies, such as delaying, holding-out, linking issues, and bandwagoning. Those strategies made the dispute settlement process more complicated, and the dispute outcomes were very unpredictable as they were dependent on the success/failure of the bargaining strategy. Moreover, power exercise in dispute resolution made trade disputes more sensitive to domestic political pressures, and, thus, a specific trade dispute frequently escalated to bitter economic and political discord. This was especially true when disputing states had similar bargaining powers, as with the US-EC disputes.

For the smaller or weaker states, the uncertainty of the GATT DS system raised more serious concerns. Given their lower income level and higher dependence on the major trading partners, their utility function can be assumed more concave (risk-averse) than that of the larger or stronger states. That is, if they lost a dispute, their utility from the lost outcome decreased more drastically as compared with the major states' utility. Moreover, under the GATT system, because disputes were frequently resolved through bilateral or minilateral negotiations among the major actors, mutual concessions achieved by dispute settlement were often applied only to the major states but not applied to all of contracting 
parties of the GATT. The principle of Most-Favored-Nation treatment (i.e., concessions to one state should be applied to all contracting states) could be ignored occasionally, and weaker states had to accept discriminative treatment. Without general procedural rules, the weaker states had greater difficulty predicting the dispute outcomes produced by the complicated bargaining and compromises.

In contrast, the WTO system significantly improved procedural provisions for dispute settlement. The most distinctive improvements in the WTO Agreements are contained in the Annex 2 Understanding on Rules and Procedures Governing the Settlement of Disputes (DSU). The DSU, as compared with the GATT DS rules, provides clearer guidelines for states to follow in filing disputes, defending disputes, adopting legal decisions, implementing final decisions, and determining the amount of remedies for compensation. Important changes under the WTO DSU are: (1) automaticity of the DS process (i.e., removing the right of blockage in adopting panel decisions), (2) time limits for each litigation process, (3) establishment of the Appellate Body, and (4) prohibition of unilateral measures without WTO approval.

Strengthened procedural rules of the DSU also contributed to encouraging states to file a dispute cases more aggressively under the WTO DS system. By eliminating blockage, introducing strict time limits, and establishing the primacy of the DSU over other dispute resolution processes, the DSU substantially reduced the uncertainties involved in resolving disputes. Disputing states now can anticipate how disputes would be handled following the substantive and procedural rules. They also can predict the approximate outcomes of the dispute. As we can see in the examples of the Banana Case (WTO DS case \#27) and the Hormone Beef Case (WTO DS case \#26), even agricultural disputes which had been the most complicated and toughest issue during the GATT period now began to be regulated under the new dispute settlement process. 5 )

\section{Risk Reduction Through Independent Legal Bodies and Legal Precedents}

The WTO system also has reduced uncertainties by means of its independent legal bodies and the legal precedents produced by those bodies. The issue of who reviews disputes and who makes final judgments is critically important not only for reinforcing

5) These two dispute cases are still in the process of implementation, provoking serious debates and conflicts between the US and EU. Although certain stalemates in these cases reflect the difficulties of dispute settlement under the WTO, especially when the two big players confront head to head with big stakes, they should not be exaggerated as if the effectiveness of the WTO DS system is fundamentally challenged. As compared with the GATT period, most cases under the WTO have been resolved and implemented rather smoothly and effectively. 
the fairness but also for increasing the stability of the dispute resolution mechanisms. Under the adjudicative system of the WTO, the member states delegated to the legal body the power of interpreting rules and making binding decisions. This increases utility for the member states by delivering more predictable dispute outcomes.

The WTO DS system consists of two legal bodies: the panel and the Appellate Body (AB). The panel is normally composed of three individuals who are selected among former or current government delegations or academics (DSU Article 8.5).6) If the disputing parties fail to agree in nominating panelists (this happened frequently and consumed considerable time during the GATT period), the Secretary has the right to nominate the panelists from Member delegations or from the Secretary's roster of individuals. So as to guarantee the independence and neutrality of the panel, no member of a disputing party can be chosen as a panelist, and the member states are prohibited from influencing the panelists with regard to matters before the panel (DSU Article 8.10).

The Appellate Body ( $\mathrm{AB}$ ) is a standing body for reviewing cases if one or both parties in dispute appeal a panel report. The $\mathrm{AB}$ consists of seven members, three of whom serve any particular case (DSU Article 17.1). The judges of the $A B$ are people of recognized authority, with demonstrated expertise in law, international trade, and the subject matter of the covered agreements (DSU Article 17.2). The jurisdiction of the $A B$ is limited to issues of law covered in a panel report and to legal interpretation developed by a panel (DSU Article 17.6). The AB may uphold, modify, or reverse the legal findings and conclusions of a panel, and the decisions of the $\mathrm{AB}$ are final with no need for further legal proceedings.

Independence, neutrality, and legal expertise are the key for the panel and the $A B$ to minimize the variations of legal decisions and to deliver predictable outcomes. Even though the WTO Agreement provides significantly clarified substantive and procedural rules, these rules cannot cover all particular aspects of the disputes that arise in real life. As incomplete contract theory suggests, the WTO Agreement is still incomplete in dealing with specific details of disputes and unforeseen contingencies. The legal bodies of the WTO are endowed with the delegated authority to fill the gap of the incompleteness. They carefully examine the case on the basis of accurate legal texts, the original purport of the agreements, and the member states' expectations created by the agreements. In making decisions, they obtain opinions from experts, investigate the proofs submitted by the disputing parties, and evaluate all claims raised by both the disputing parties and third-party participants. Because of neutrality in the composition of the legal bodies and expertise in interpreting legal provisions, the adjudicative system of the WTO could

6) When the disputing parties agree, a five-member panel is also possible. 
produce high-quality decisions with legal consistence.7)

Although states do not acknowledge the legal precedents in the WTO DS system, the accumulated legal decisions made by the panel and the $A B$ in fact have effects similar to those of legal precedents on the member states. Legal precedents have helped to reduce uncertainties and have improved the predictability of the dispute outcomes. Maintaining legal consistency and coherency in their decisions is absolutely necessary if the legal bodies of the WTO are to acquire a good reputation with the member states. Thus, the legal bodies endeavor to consult former decisions and to reach decisions that are harmonious with existing judgments. This tendency is especially distinctive in the Appellate Body. In reviewing legal interpretation developed by a panel, the $A B$ frequently reiterates its former decisions, extracts relevant principles established in the former decisions, and applies them to the new case. ${ }^{8)}$ Fearing reversal by the $A B$, panel rulings also have become more legalistic and strict in their reasoning, explicitly citing previous panel and appellate body rulings (Alter 2001, p. 34).

Legal precedents have a considerable influence on the behavior of the member states. Established precedents can project the shadow of the law in and out of the court, facilitating formal and informal solutions for disputing matters. As Alter (2001, p. 1) points out, the effective legal systems build a comprehensive, consistent and coherent web of legal precedent that can guide state decision-making. Although foresight is not perfect, by examining the former decisions on similar issues states are able to anticipate the consequences of a dispute more accurately. Legal precedents generate stable expectations for dispute outcomes, and, as a result, they reduce the degree of variation of the outcomes. This explains how the legalized DS system of the WTO reduces risks and increase utility for the member states.

\section{Risk Creation by the Legalized DS Mechanism}

So far, I have discussed how the legalized DS mechanism of the WTO reduces some

7) In an interview that I conducted with a Korean Deputy Director (Summer, 2001), Multilateral Trade Cooperation Division, Ministry of Foreign Affairs and Trade (MFAT), he emphasized that the high quality of the panel/appellate body decisions and fairness in the operation of legal bodies are the key reasons that states have complied with the decisions in most cases.

8) As one of these examples, see Appellate Body Decision on United States Safeguard Measures on Imports of Fresh, Chilled or Frozen Lamb Meat from New Zealand and Australia (WTO DS Case $\# 177$, Case \#178). In making decisions, the $\mathrm{AB}$ referred to its former decisions on Argentina Footwear Safeguards and Korea Dairy Safeguards, and it indicated legal errors committed by the panel. 
types of risks/uncertainties involved in dispute outcomes. I would emphasize, however, that legalization does not reduce all risk monolithically. To the contrary, the legalized DS system actually produces risk that derives from the delegated power of the independent legal bodies. As I will demonstrate, the key features of the WTO DS system its delegated authority and independence reduce one type of risk but simultaneously increase another type of risk that the states have to consider when they construct the legal system.

To gain a better understanding of risk creation by the legalized DS system, it is necessary to differentiate the different types of risks involved in the dispute settlement. When I discuss the risk-reduction effects of legalization, I focus on the degree of variation or fluctuation of dispute outcomes. Risk reduction implies low variations of dispute outcomes, and the baseline of comparison is the outcome that results through use of the non-legal bargaining DS mechanism. On the other hand, when I regard the risk-creation aspect of legalization, I refer to the danger that actual outcomes produced by the legalized DS system might deviate from what the states expected when they originally agreed to be bound by the new legal system. When the states reached the original agreement through detailed negotiations over the content of the law, that agreement generated certain expectations about the distributive consequences. That is, states had broad expectations about the costs and benefits that would ensue by these giving and taking concessions with one another.

Legalization entails the risk that the independent legal bodies may produce outcomes that differ from those the member states expect. States are seriously concerned about the possibility that legal decisions will be systematically biased against them or that distributive consequences produced by the legal decisions will be unfavorable to them. Moreover, because the legal bodies are delegated the authority to interpret the law and to make binding decisions on disputes, states may worry that the independent legalized system will result in an autonomous and prerogative entity that cannot be controlled by the member states.9)

Legal precedents developed by the legal body also contribute to increasing this type of risk and uncertainty. Because legal precedents extend the distributive consequences of one decision to the future for use in making similar decisions, the impacts of the precedents are accumulative on the member states. Thus, acknowledging legal precedents with general applicability involves considerable risk in that it widens the gap between the

9) Risk creation by the legalized DS system is similar to the classic principal-agent (PA) problem. However, unlike the PA, my argument does not presume an agent who pursues its own interest against the interest of a principal. I simply indicate the possibility that the actual outcomes produced by the DS system deviate from the original expectation of the regime designers (states). 
original expectation and actual outcomes over time. Due to these concerns, states generally do not accept the principle of legal precedents in arranging their relationships through international law. This is also the case in the WTO DS system. The WTO Agreement manifests that the legal decision made in one case does not have any binding power for other decisions as legal precedents and that each case should be treated separately on its own. As Reitz (1996, p. 586) pointed out, the Uruguay Round negotiators were not unaware of the law-making potential of the GATT dispute resolution mechanism, particularly the ability of the Appellate Body to shape and develop GATT law through the power of precedent.

Constructing legal institutions and resolving disputes through the legalized DS system is still an attractive option for states since legalization can reduce dispute settlement costs significantly as well as reduce the wide variations of dispute outcomes that occurred in the non-legal bargaining DS system. However, because states also keenly understand the risk entailed by legalization, they incorporate several measures to handle the risk when they established the legal system. First of all, the states introduce regular renegotiation mechanisms to adjust for the difference between the original expectations and the actual outcomes. The WTO Agreement has mandatory provisions that the Ministerial Conference, which is composed of representatives of all members, should meet every two years. As the highest level body of the WTO organization, the Ministerial Conference mainly assumes the functions of rule-making, which enables states to renegotiate terms of agreements in order to adjust unexpected consequences.

Second, states are very careful in determining the degree of discretion that can be exercised by independent legal bodies. The delegated authority from the member states to the legal body is not an unlimited one, and it is restricted and governed by the substantive and procedural rules agreed to by the states. The panel and the Appellate Body of the WTO are also aware of member states' concerns about abuse of delegated power. Thus, they tend to be cautious in interpreting and applying the law so that their decisions do not go beyond the legal texts and original purports of agreement provisions.

Finally, if disputes are purely determined by the legal process that differentiates right from wrong, the outcome might be too strict and burdensome for the losing party to implement immediately. When some countries expressed concerns about the abuses of legal mechanisms during the Unuguay Round negotiations, they pointed out the risk that the dispute outcomes from a legal mechanism might have, ironically, wider variations than outcomes from a non-legal bargaining mechanism. Because of these concerns, although the legalized DS system is based on binding legal obligations, it also allows a substantial amount of room for reaching mutually acceptable solutions through political bargaining. 
The DSU requires 60 days of a mandatory consultation period before entering into formal litigation. Even after the formal process begins, if the disputing parties reach mutually agreeable solutions during any step of the legal process, they can withdraw the case. Another mechanism that facilitates political bargaining is found in the binding arbitration process that determines the amount of remedies in cases of violations. The arbitration body which is, in fact, the reconvened panel when disputing parties cannot reach the agreement on the amount of remedies makes an effort to determine the mutually acceptable amount of remedies, and, thus, the amount tends to be determined around the mid-point of the complainant's and defendant's estimations. That is, through adjustment in determining the amount of remedies, the arbitration process helps avoid outcomes that are too extreme to be implemented by the losing party.

\section{Conclusion}

This article has explored two contrasting types of risk/uncertainty problems that are related to international legalization: risk reduction and risk creation. Given that there has been no systemic analysis concerning the various aspects of risk/uncertainty problems in the context of international legalization, this study intends to fill the theoretical and empirical gap of existing studies.

The first argument in this article is that states can reduce risk/uncertainty and increase utility by arranging their relations through international law. Focusing on dispute settlement mechanisms, I contend that clarified substantive rules, well-established procedural rules, independent legal bodies, and legal precedents the four features of the legalized DS mechanism can reduce the risk/uncertainties involved in dispute resolution. As compared with the non-legal bargaining mechanisms of dispute resolution, the legalized DS system tends to produce dispute outcomes with narrower variations and smaller fluctuations. Assuming the risk-averse utility function of rational actors, we can understand how the legalized DS system improves utility among disputing states by reducing uncertainties.

Although the legalized DS system does reduce the variation of dispute outcomes, it also creates a certain type of risk resulting from the independence of the legal institutions. The risk creation aspect of the legalized DS system is the second topic of this article. Because binding decisions are made by the independent third party with delegated authority and because legal precedents have accumulative effects on distributional consequences, the states are significantly concerned that the actual outcomes produced by the legal bodies may deviate from their expectations at the time of the original legalization 
agreement. Thus, the states in legal arrangements try to limit the authority of the legal bodies. Regularizing renegotiations for adjustment, restricting the boundaries of interpretive discretion, facilitating mutually agreeable solutions through political bargaining, and not acknowledging the principle of legal precedents all these mechanisms are employed to handle the risks that may be produced by the establishment of the legalized DS system. 


\section{References}

Abbott, Kenneth and Duncan Snidal. 2000. Hard and Soft Law in International Governance. International Organization 54:421-456.

Alter, Karen J. 2002. International Legal Systems, Regime Design and the Shadow of the Law in International Relations. A paper presented at the 2002 annual meeting of the American Political Science Association. Boston. August 28-September 1.

Bayard, Thomas O. and Kimberly Ann Elliott. 1994. Reciprocity and Retaliation in U.S. Trade Policy. Washington D.C.: Institute for International Economics.

Bhagwati, Jagdish. 1990. Aggressive Unilateralism: An Overview. In Aggressive Unilateralism: America's 301 Trade Policy and the World Trading System, edited by Bhagwati and Patric. Ann Arbor: University of Michigan Press.

Croome, John. 1995. Reshaping the World Trading System: A History of the UR. Hague, Kluwer Law.

Helfat, Constance E. and David J. Teece. 1987. Vertical Integration and Risk Reduction. Journal of Law, Economics, and Organization, 3 (1): 47-67.

Hirschman, Albert O. 1980 (1945). National Power and the Structure of Foreign Trade. Expanded Edition. Berkeley: University of California Press.

Hoekman, Bernard M. and Norstrom Mavroidis. 2000. WTO Dispute Settlement, Transparency and Surveillance. World Economy 23 (4):527-42.

Hudec, Robert E. 1993. Enforcing International Trade Law. Salem, NH: Butterworth Legal Publishers.

Hudec, Robert E. 1999. The New WTO Dispute Settlement Procedure: An Overview of the First Three Years. Minnesota Journal of Global Trade 8:1-53.

International Organization. 2000. Vol. 54, No. 3. Summer.

Jackson, John H., William J. Davey, and Alan O. Sykes. 1995. Documents Supplement to Legal Problems of International Economic Relations. $3^{\text {rd }}$ Edition. West Group. Jackson, John H., William J. Davey, and Alan O. Sykes. 2002. Legal Problems of International Economic Relations: Cases, Materials, and Text. Fourth Edition. West Group.

Keohane, Robert O. and Joseph S. Nye. 1989. Power and Interdependence. $2^{\text {nd }}$ Edition. HaprCollins Publishers.

Klein, B., Crawford, R.A., and Alchian Armen A. 1978. Vertical Integration, Appropriable Rents, and the Competitive Contracting Process. Journal of Law and Economics 21:297-326.

Knight, Frank H. 1965. Risk, Uncertainty, and Profit. New York: Harper and Row. 
Koopmans, Tjalling C. 1957. Three Essays on the State of Economic Science. New York: McGraw-Hill.

Mattli, Walter. 2001. Private Justice in a Global Economy: From Litigation to Arbitration. International Organization.55 (4): 919-947.

Moon, Don. 2002. Governing the Court: The Political Economy of the WTO Dispute Settlement System. Ph.D. Dissertation. University of Chicago

Mullainathan, Sendhil and Richard H. Thaler. 2000. Behavioral Economics. NBER Working Paper Series 7948.

Reitz, Curtis. 1996. Enforcement of the General Agreement on Tariffs and Trade. University of Pennsylvania Journal of International Economic Law 17:555-603.

Schwartz, Warren and Alan O. Sykes. 2001. The Economic Structure of Renegotiation and Dispute Resolution in the WTO/GATT System. A paper prepared for a conference at the University of Chicago Law School. April.

Silverman, Jared R. 1996. Multilateral Resolution Over Unilateral Retaliation: Adjudicating the Use of Section 301 Before the WTO. University of Pennsylvania Journal of International Economic Law 17 (1):233-294.

Smith, James McCall. 2000. The Politics of Dispute Settlement Design: Explaining Legalism in Regional Trade Pacts. International Organization 54 (1):137-180.

Stewart, Terence P. ed. 1993. The GATT Uruguay Round: A Negotiating History (1986-1992) Volume II: Deventer, Boston: Kluwer Law and Taxation Publishers. Sykes, Alan O. 1992. Constructive Unilateral Threats in International Commercial Relations: The Limited Case for Section 301. Law and Policy in International Businesses 23:263-330.

Whalley, John and Colleen Hamilton 1996. The Trading System After the Uruguay Round. Washington D.C.: Institute for International Economics.

Williamson, Oliver E. 1979. Transactions-Cost Economics: The Governance of Contractual Relations. Journal of Law and Economics 22:233-261.

Williamson, Oliver E. 1989. Transaction Cost Economics. In Handbook of Industrial Organization. Vol. 1. edited by R. Schmalensee and R.D. Willig. Elsevier Science Publishers B.V.

World Trade Organization. Overview of the State-of-Play of WTO Dispute. www.wto.org/wto/dispute/bulletin.htm.

Yarbrough, Beth V. and Robert M. Yarbrough. 1997. Dispute Settlement in International Trade: Regionalism and Procedural Coordination. In The Political Economy of Regionalism, edited by Edward D. Mansfield and Helen V. Milner, pp. 134-163. New York: Columbia University Press. 